\title{
The downside to big data: What triggers a backlash response in consumers to marketing?
}

\author{
Matthew Vollrath \\ Ohio Wesleyan University \\ Robert A. Lloyd \\ Fort Hays State University
}

The idea of target marketing evolved from the 1960s change in business thinking that resulted in companies focusing on the customer instead of production and efficiency. The use of big data in marketing coupled with advances in technology since that time have afforded companies new ways to communicate increasingly targeted messages to their customers. These marketing efforts have been received both positively and negatively by the customer and have uncovered a variety of issues. Messages that connect with a self-identity of the consumer or make a connection to a reference group are well received. In addition, when a company receives permission to send targeted messages the consumer responds favorably. However, when the consumer perceives a violation of privacy occurred, or the message propagates a racial stereotype, consumers tend to respond negatively. This paper reviews the major issues that trigger positive and negative responses along with factors that trigger a backlash. Recommendations for future research are provided which include how different generations respond to target marketing as well as how companies respond to consumer backlashes.

\section{INTRODUCTION}

Taylor's (1911) work on scientific management embodied the predilection of management practice from the era of the industrial revolution through the 1950s where production and efficiency commanded most of the American manager's attention (Cranier, 2006). Drucker (1954) challenged this viewpoint with the prescient notion that "there is only one valid definition of business purpose: to create a customer" ( $\mathrm{p}$. 37). Levitt (1960) claimed that a focus on production means that marketing gets sacrificed, and he urged industries to focus primarily on the expressed and implied needs of their customers, while Gailbreth (1958) argued that it was marketing and advertisement itself that created demand for products, creating in customers a dependency on the product and resulting in increased profitability. The work of Levitt and Drucker revolutionized how businesses looked at the market place, where response to consumer needs dictated profitability (Cranier, 2006).

A preponderance of research has emerged since the work of Drucker and Levitt as firms have embraced marketing and advertising as essential business functions. More specifically, businesses have identified target markets by endeavoring to understand which customers are interested in the products they offer. Kotler, Armstrong, and Starr (1991) defined target marketing as an identification of a set of 
buyers sharing common needs or characteristics that a company decides to serve. Target marketing can be attributed to the success of many brands (Aaker, Brumbaugh, \& Grier, 2000), and works under the assumption that the interested buyers can identify with the brand of the company (Aaker, 1999).

The benefits of branding and target marketing notwithstanding, marketing messages need to be sent within the context of a few ethical considerations. Advertising should be a tool to educate the customer about a company's product or brand and not target individuals who lack the rational ability to make independent decisions (DesJardins, 2011). Marketing messages that appeal to vulnerable customers based on their fears, anxieties, or deep feelings of guilt are considered manipulative because they treat consumers as a means (to profitability) and do not respect their dignities as human persons (Kant, 1993).

The purpose of this paper is to summarize the literature on big data as it relates to how the customer responds both positively and negatively to companies' efforts to win their business through targeted advertising and sales. In addition, the factors that contribute to a consumer backlash to target marketing will be explored and illustrated with examples. Finally, recommendations for future research on the subject of target marketing are presented.

\section{Big Data and Marketing}

Big data is a reality of business and has impacted not only how businesses operate (Yamamoto \& Lloyd, 2019), but in how they interact with stakeholders (Seele, 2017). The marketing tactics employed by companies in the recent decade have promulgated public calls for privacy protection. The advances in cell phones, database capabilities, and the growth of the internet have allowed companies to discover valuable insights about their customers which have led to more precise marketing messages to targeted audiences (Dobrow, 2015). Mobile communication is now considered the primary means of communication (Vlad, 2011) and this digital advertising channel can reach audiences much quicker - "97 percent of all text marketing messages . . . are opened, and 83 percent of those are opened within one hour" (Cohen, 2009, para. 3). Consumers continue to allow their personal information to be distributed and collected by signing up for email distribution lists, registering for mobile applications, and posting on their social media accounts while consumers' browsing history and activities on auction websites provides information to businesses about how consumers process price information (Kumar, Xi, \& Luo, 2014; Drèze, 2005).

Database marketing relies on "accurate, timely, and thorough" (McKinney, Morales Olazábal, Cava, \& Sacasas, 2003, p. 214) information about consumers. Businesses utilize a customer analytics tool referred to as data mining to conduct their analysis of such large volumes of information (Corrigan, Craciun, \& Powell, 2014; Alexander, 2013). Data mining is one tool that marketers use to recognize the characteristics of the target market using statistical algorithms that identify purchasing patterns, anomalies and relationships. Furthermore, data mining can produce probabilities around when customers are likely to make their next purchase (Donaldson, 2007). Data mining and database marketing are means to reach the target market through focused messaging to the intended audience.

Cespedes and Smith (1993) suggested that data mining improves efficiency in marketing efforts by allowing marketers to engage in targeting, tailoring, and tying. The use of data mining helps businesses reduce wasteful marketing budgets on unintended market audiences, which allows them to target customers who will be more likely buy their products. They can tailor specific messages that will be well received by the intended target, and they can tie relationships together by creating products and messages their customers want.

\section{LITERATURE REVIEW}

Companies have successfully used big data and target marketing to build a positive brand image as well as solicit loyalty from their current customer base. The marketing strategies that receive a positive response make connections with the consumer's self-identity and with their association with ethnic, racial, or other reference groups. Additionally, customers respond more favorably to advertisements from companies when they are first asked permission to have marketing communications sent to them (Godin, 
1999). These factors that lead to a positive customer response to target marketing will be discussed in this section.

\section{Self-identity}

Research indicates positive effects of branding exist when the message appeals to a consumer's selfidentity. More simply stated, customers are attracted to products they feel reflect their identity as a person (Stayman \& Deshpande, 1989), their personality (Aaker, 1997), or what that consumer may aspire to reach (Belk, 1988). Making this connection to the self-identity has been shown to make customers internalize the brand as a part of themselves (Kleine, Kleine, \& Allen, 1995).

Self-identity can reflect not only a person's individualism, but also to their relationship to a social group (Lloyd \& Mertens, 2018). Escalas and Bettman (2005) found that individuals who identified with a social group were more open to accepting brands originating out of their social group than were individuals considered to be more independent. However, making a connection to identification with a social group must go beyond advertising that emphasizes feature based or counterfactual arguments (Bolton \& Reed, 2004). Eliciting a positive response to target marketing must focus on social identifications that are salient within the individual and keep in mind that a consumer's self-identity is a "sum total of his or her social identities" (Reed, 2004, p. 292).

\section{Racial and Ethnic Identity}

The appeal to racial identity is a prevalent advertising practice and has proven to be successful (Reed, 2004). However, research shows that simply using people that are categorized into the same ethnic or racial background as the target market in pictures, radio, or television is not enough to elicit identification with the consumer. The message must be delivered in venues or times when the target market is feeling particularly disposed to receive the message, or the identification with their racial or ethnic identity is salient (Forehand \& Deshpande, 2001). Additionally, the growing diversity within the U.S. has resulted in a fragmented system of sub-cultures. The target marketing must take into account the various subtleties of the geographic or regional differences between members of the same race (Green, 1999).

\section{Permission-based Marketing}

In response to a public outcry of privacy concerns regarding unsolicited marketing communications, companies engaged in permission-based marketing where they would first ask the consumer if they could send marketing communications (Godin, 1999). Permission-based marketing assumes that over time, the company will be able to meet the needs of the consumer more adequately and in response, the customer would grant the company more access to their personal information. Kent \& Brandal (2003) found that consumers who first granted permission to companies were apt to open direct mail and email advertisements as well as respond to company marketing efforts. Permission-based marketing puts the control back into the hands of the consumer as they slowly relinquish access to their personal information. This slow process of trust building creates more loyal and profitable customers as a result (MacPherson, 2001).

\section{Target Marketing and a Negative Response}

In some cases, consumers do not respond well to a company's efforts to strategically target their perceived needs. Several factors can create an unfavorable response and can trigger a consumer backlash. This response begs the question - how do customers respond negatively to target marketing and what triggers the backlash? These determinants will be explored in the following section.

\section{Privacy Concerns}

Research shows that the consumer backlash to target marketing stems from what consumers view as violations of privacy (Milne \& Rohm, 2000). The need for protections of privacy was first put forth by Warren and Brandeis (1890) as they declared that individuals had the "right to be let [sic] alone" (p. 193), and during a speech in 1962 President Kennedy suggested privacy as a consumer right (Goodwin, 1991). 
Throughout the 1970s and 1980s, the inconvenience of direct mailings and telemarketing calls to households prompted public outrage of invasions of privacy. New technologies in the 1980's allowed companies to survey, retrieve, store and communicate personal information like never before (Bennett, 1992). Database marketing and telemarketing contributed to a growing public concern about how companies used their personal information as companies collected information via "product warranties, 800 numbers, retail scanners, and web site visits" (Milne \& Rohm, 2000, p. 238). Primary among the public's concern was that information about them was being collected, sold, and analyzed without their consent (Clarke, 1988).

In response to the telemarketing practices, several laws and administrative regulations were established to protect consumer privacy. The Telephone Consumer Protection Act (TCPA) of 1991, the Telemarketing Consumer Fraud and Abuse Act of 1994, and the Telemarketing Sales Rule were first attempts to protect consumer privacy (Baker, 2014). The TCPA made it illegal to send unsolicited messages via "facsimile, automated recorded messages, advertising calls to cellular telephones. . . and solicitation after consumers have included their names on the no-call list" (Baker, 2014, p. 84). In 2012, the Supreme Court case Mims v. Arrow Financial Services, LLC further limited advertising to include text messaging as a prohibitive form of solicitation (Corcoran, Rachman, \& Greenberg, 2014) and in 2009, in Satterfield v. Simon and Schuster May, companies could no longer use third parties to send messages on their behalf (Lacy, 2010).

Consumers consider their right to privacy violated when they can no longer control their social or their physical interactions (Laufer, Proshanskey, \& Wolfe, 1976). Conversely, research has shown that consumers do not consider a company to violate their privacy when their personal information is collected through an existing relationship (primary sourcing), they can maintain a sense of control of the information, the collected information is pertinent to the business interaction with the company, and they believe the company will use the information in good faith (Culnan, 1993).

\section{Backlash Triggers}

Invasion of privacy via use of personal information is certainly the primary catalyst for consumer backlash. But there are additional factors that contribute to a consumer's negative response. Thomas, Trump, and Price (2015) describe a phenomenon they refer to as the "dirty laundry effect" (p. 58), whereby an advertisement is successful in appealing to a self-identity of a consumer, but the consumer would rather not have that identity become portrayed to the general public. In addition, while using ethical appeals is shown to be an effective marketing strategy, when the portrayal of those images is done using ethnic or racial stereotypes, the members of that ethnic group respond negatively. Permission-based marketing works well because the company is collecting primary data from the customer, but Culnan (1993) found that when a company targets consumers using information they received from secondary sources, the response is again negative.

Environmentally conscious consumers during the 1990's were promised advances and offerings of "green" products during that era, but companies did not deliver on their promises to the target market (Wong, Turner, \& Stoneman, 1996). In this case the initial response to target marketing was favorable, but not following through resulted in a negative response. Finally, customers who are loyal to a particular industry respond negatively when they are offered repackaged versions of the same goods they have already been consuming and nothing new of value is being created (Plasketes, 2008).

\section{Modes of Consumer Backlash}

The triggers described in the previous section can lead to responses such as a few individuals boycotting a particular good or can be much more drastic and impactful to a company's profitability. The extreme responses can take the form of media led attacks against the company which tarnish their reputation, public campaigns to boycott their goods, competitors using the negative response to gain an advantage, or legislation that hinders an industry's ability to engage in certain forms of target marketing (Cespedes \& Smith, 1993). In the food industry, consumers respond negatively to the target marketing of high calorie and high fat foods by blaming the companies themselves (Reyes, 2003). Others respond by 
requesting to be taken off the list of contacts or have their personal information removed, known as opting-out (Milne \& Rohm, 2000).

\section{Backlash Examples}

What seems to be the most publicized debate regarding target marketing is the response to pharmaceutical companies targeting doctors. Sales representatives regularly take doctors out to expensive meals and entertainment in an effort to get them to prescribe their company's medicine. This is a form of target marketing inasmuch as the doctors' needs are identified and catered to through the messages provided by pharmaceutical salesmen. The public decries this form of target marketing because they see a conflict of interest in having doctors persuaded by factors outside of the best medical solutions to a patient's condition (Singer, 2007). A father in Minnesota was outraged that Target sent his daughter deals on maternity products. Target had tracked his daughter's purchases and surmised that she was pregnant, which she in fact was (Duhigg, 2012). The backlash in this instance took place in the negative publicity the company received when the New York Times published the story.

High school seniors responded to the negative efforts of college recruiting by claiming they simply wanted authenticity and honesty when the schools attempted to recruit them (Heckscher, 1978). Lotus created an enormous database containing household and lifestyle information about consumers called MarketPlace. The public saw this as a violation of their privacy and 30,000 people asked to be removed from list as the issue was discussed in the media and in Congress (Miller, 1991b). Blockbuster Video intended to sell the information about its customers and their buying habits but decided to stand down after public outrage (Miller, 1990). Finally, amid the negative response to telemarketers during the 1990 's, a private citizen organized a task force, Private Citizen Inc., to collect information about the companies making calls to private homes in their area. They subsequently sent contracts to the telemarketing companies indicating that they would accept the phone calls in the future if the company agreed to pay them a $\$ 100$ fee (Miller, 1991a). In some cases the companies returned calls and paid the fee.

\section{DISCUSSION}

The effects of big data and target marketing are covered extensively in the literature. The purpose of this paper was to review the history of how consumers respond to target marketing. The research shows there are both positive and negative consequences. However, there are several gaps in the research that need to be addressed through future research.

First, almost no attention is given to how companies respond to the customers' reactions. Nevertheless, a few examples of companies can demonstrate the wide variance of responses. AOL Time Warner responded to negative publicity by suing the vendors that were sending unsolicited advertising (Crichard, 2003). A small business owner in Oregon sued the federal legislation on the grounds that telemarketing limitations were discriminatory to small businesses that depended on it as an essential channel (Washington Post, 1992). Research demonstrates a clear connection between CSR and financial outcomes (Lloyd, 2017), but little is known about how companies are using big data to improve their CSR efforts, particularly in response to consumer demands. Target, Inc. responded to the negative publicity of the maternity marketing case by inundating customers with even more mailings, under the guise of hiding the targeted messages among a prodigious number of other marketing messages that probably would not receive customer response (Duhigg, 2012). Several companies took a pre-emptive approach to customer backlash by setting their own limits on target marketing (Cespedes \& Smith, 1993; Crane, 2000; Thomaselli, 2008) and by getting involved in the lobbying efforts of legislation surrounding marketing limitations so as to prevent unreasonable or overly burdensome regulations (Bloom, Milne, \& Adler, 1992). These examples are not representative of a single industry and do not provide insights on how the majority of companies respond. Therefore, future research needs to explore the issue.

A second topic for future study is how different generations might respond to target marketing. Generation Y's consists of 80 million people born between 1980 and 2000, and are the most recent group 
of people to join the American workforce (VanMeter, Grisaffe, Chonko, \& Roberts, 2013). How does Generation Y respond to marketing efforts in a world where advertising messages are constantly coming at them through an increasing variety of mediums? Historically, consumer backlash has occurred via media-led campaigns. Modern consumers have the ability to create a lot of buzz through social mediums such as Twitter and Facebook and do not need the media to help propagate a backlash. Research needs to be conducted in 1) how Generation Y characteristics dispose them differently to target marketing than what the last two decades of literature report and 2) in what forms (e.g. social media) can backlash now occur? Additionally, the phenomenon needs to be studied in the context of backlashes as they appeared in past and the current form of backlashes inasmuch as the impact to the company can be measured.

\section{CONCLUSION}

This paper reviews the literature on target marketing and the response it elicits from consumers. When done well and within the boundaries of what consumers deem acceptable, target marketing is received positively by the targeted audience. For example, the appeals to self-identity, social group of the individual, or identification with an ethnic group can be highly effective advertising. However, when violations of privacy occur, the message portrays an image the target market dislikes (e.g. stereotypes or images that while true, are not something they want to be shown), or the company does not follow through with the message they communicate, backlash occurs. This takes the form of media-led campaigns, consumer boycotts, and in some cases national and state legislation. Several gaps in the research exist that need to be explored through future research.

\section{REFERENCES}

Aaker, J., Brumbaugh, A., \& Grier, S. (2000). Nontarget markets and viewer distinctiveness: The impact of target marketing on advertising attitudes. Journal of Consumer Psychology, 9(3), 127-140.

Aaker, J. (1999). The malleable self: The role of self-expression in persuasion. Journal of Marketing Research, 36, 45-57.

Aaker, J. L. (1997). Dimensions of brand personality. Journal of Marketing Research, 34(3), 347-356.

Alexander, D. (2012). Data Mining. University of Texas. Retrieved from www.laits.utexas.edu anorman/BUS.FOR/course.mat/Alex/

Baker, W. B. (2014). The complications of doing mobile marketing legally. Journal of Internet Law, 17(8), 13-25.

Belk, R. W. (1988). Possessions and the extended self. Journal of Consumer Research, 15(2), 139-168.

Bennett, C. J. (1992). Regulating privacy: Data protection and public policy in Europe and the United States. Ithaca, NY: Cornell University Press.

Bloom, P. N., Milne, G. R., \& Adler, R. (1992). A framework for identifying the legal and political risks of using new information technologies to support marketing programs. Marketing Science Institute. Retrieved from http://www.msi.org/reports/a-framework-for-identifying-the-legal-andpolitical-risks-of-using-new-info/

Bolton, L. E., \& Reed II, A. (2004). Sticky priors: The perseverance of identity effects on judgment. Journal of Marketing Research, 41(4), 397-410.

Brown, D. B. (2010). Class actions under the Federal Telephone Consumer Protection Act of 1991. FDCC Quarterly, 61(1), 84-98.

Cespedes, F. V., \& Smith, H. J. (1993). Database marketing: New rules for policy and practice. Sloan Management Review, 34(4), 7-22.

Clarke, R. A. (1988). Information technology and dataveillance. Communications of the ACM, 31(5), 498-512.

Cohen, M. (2009). A small business guide to text-message marketing. New York Times. Retrieved from http://www.nytimes.com/2009/09/24/business/smallbusiness/24texting.html?pagewanted=all 
Corcoran, P. F., Rachman, M. J., \& Greenberg, D. S. (2014). The Telephone Consumer Protection Act: Privacy legislation gone awry? Intellectual Property \& Technology Law Journal, 26(10), 9-15.

Corrigan, H. B., Craciun, G., \& Powell, A. M. (2014). How does Target know so much about its customers? Utilizing customer analytics to make marketing decisions. Marketing Education Review, 24(2), 159-166.

Crane, A. (2000). Facing the backlash: Green marketing and strategic reorientation in the 1990s. Journal of Strategic Marketing, 8(3), 277-296.

Cranier, S. (2006). The ultimate business library: The greatest books that made management. West Sussex, England: John Wiley \& Sons, Ltd.

Crichard, M. (2003). Privacy and electronic communications. Computer Law \& Security Review. 299.

Culnan, M. J. (1993). How did they get my name? An exploratory investigation of consumer attitudes toward secondary information use. MIS Quarterly, 17(3), 341-363.

DesJardins, J. (2011). An introduction to business ethics. 4th Ed. New York, NY: McGraw Hill.

Dobrow, L. (2015). Tread carefully on privacy; Beware of e-consumer backlash. Advertising Age, 29.

Donaldson, S. A. (2007). Profiting from consumer behavior. Black Enterprise, 37(8), 94.

Drèze, X. (2005). Lessons from the front line: Two key ways in which the internet has changed marketing forever. Applied Stochastic Models in Business and Industry, 21(4/5), 443-448.

Drucker, P. F. (1954). The Practice of Management, New York, NY: Harper and Row.

Duhigg, C. (2012). How companies learn your secrets. New York Times. New York, NY.

Escalas, J. E., \& Bettman, J. R. (2005). Self-construal, reference groups, and brand meaning. Journal of Consumer Research, 32(3), 378-389.

Forehand, M. R., \& Deshpande, R. (2001). What we see makes us who we are: Priming ethnic selfawareness and advertising response. Journal of Marketing Research, 38(3), 336-348.

Galbraith, J. (1958). The Affluent Society. Boston, MA. Houghton Mifflin.

Godin, S. (1999). Permission Marketing: Turning Strangers into Friends, and Friends into Customers. London, UK. Simon \& Schuster.

Goodwin, C. (1991). Privacy: Recognition of a consumer right. Journal of Public Policy and Marketing, 10(1), 149-166.

Green, C. L. (1999). Ethnic evaluations of advertising: Interaction effects of strength of ethnic identification, media placement, and degree of racial composition. Journal of Advertising, 28(1), 49-64.

Heckscher, S. (1978). Marketing backlash: Students react to the admissions chase. Journal of The National Association of College Admissions Counselors.

Kant, E. (1993). Grounding for the Metaphysics of Morals: On the Supposed Right to Lie because of Philanthropic Concerns. (J. Ellington, Trans). Indianapolis, IN. Hackett Publishing. (Original work published 1785)

Kent, R., \& Brandal, H. (2003). Improving email response in a permission-marketing context. International Journal of Market Research, 45(4), 489-503.

Kotler, P., Armstrong, G., \& Starr, R. G. (1991). Principles of Marketing ( $5^{\text {th }}$ ed.). Englewood Cliffs, NJ: Prentice Hall.

Kleine, S. S., Kleine III, R. E., \& Allen, C. T. (1995). How is a possession "me" or "not me"? characterizing types and an antecedent of material possession attachment. Journal of Consumer Research, 22(3), 327-343.

Kumar, V., Xi, Z., \& Luo, A. (2014). Modeling customer opt-in and opt-out in a permission-based marketing context. Journal of Marketing Research, 51(4), 403-419.

Lacy, G. S. (2010). Mobile marketing derailed: How curbing cell phone spam in Satterfield V. Simon \& Schuster may have banned text message advertising. Washington Journal of Law, Technology and Arts, 6(1).

Lloyd, R. A., \& Mertens, D. (2018). Expecting more out of Expectancy Theory: History urges inclusion of the social context. International Management Review, 14(1), 28-43. 
Lloyd, R. A. (2017). The impact of CSR efforts on firm performance in the energy sector. Review of Integrative Business and Economics Research, 7(3), 25-65.

Laufer, R. S., Proshansky, H.M., \& Wolfe, M. (1976). Some analytic dimensions of privacy. In H.M. Proshansky, W.H. Ittelson, \& L.G. Rivlin (eds), Environmental Psychology: People and Their Physical Settings ( ${ }^{\text {nd }}$ Ed). New York, NY: Holt, Rinehart and Winston.

Levitt, T. (1960). Marketing myopia. Harvard Business Review, 38(4), 45-56.

MacPherson, K. (2001). Permission-based Email Marketing that Works! London, UK. Dearborn Trade.

McKinney, B., Morales Olazábal, A., Cava, A., \& Sacasas, R. (2003). Are mailing lists protected free speech? despite dissent, the supreme court remains silent. Journal of the Academy of Marketing Science, 31(2), 214-215.

Miller, M. W. (1991a). When the junker calls, this man is ready for revenge. Mr. Bulmash leads charge against telemarkers; and they often pay up. The Wall Street Journal.

Miller, M.W. (1991b). Lotus is likely to abandon consumer data project. Wall Street Journal, 23, p. B1.

Miller, M.W. (1990). Coming Soon to Your Local Video Store: Big Brother. Wall Street Journal, 26, p. 10.

Milne, G. R., \& Rohm, A. J. (2000). Consumer privacy and name removal across direct marketing channels: Exploring opt-in and opt-out alternatives. Journal of Public Policy \& Marketing, 19(2), 238-249.

Plasketes, G. (2008). Pimp my records: The deluxe dilemma and edition condition: bonus, betrayal, or download backlash? Popular Music and Society, 31(3), 389-393.

Reyes, Sonia. (2003). Fighting the FAT backlash. Brandweek, 44(18), 24.

Rothfeder, J. (1992). Privacy For Sale. New York, NY: Simon \& Schuster, pp. 102-105.

Seele, P. (2017). Predictive Sustainability Control: A review assessing the potential to transfer big data driven 'predictive policing' to corporate sustainability management. Journal of Cleaner Production, 153(1), 673-686.

Singer, E. (2007). Aggressive drug marketing tactics trigger backlash. Nature Medicine, 13(4), 393.

Stayman, D., \& Deshpande, R. (1989). Situational ethnicity and consumer behavior. Journal of Consumer Research, 16(3), 361-371.

Thomas, T. C., Trump, R. K., \& Price, L. L. (2015). Advertising as unfavorable self-presentation: The dirty laundry effect. Journal of Advertising, 44(1), 58-70.

Thomaselli, R. (2008). Pharma biz cops to \$5B drug problem. Advertising Age, 79(4), 3-39.

VanMeter, R., Grisaffe, D., Chonko, L., \& Roberts, J. (2013). Generation Y's ethical ideology and its potential workplace implications. Journal of Business Ethics, 117(1).

Warren, S.D., \& Braneis, L.D. (1890). The right to privacy. Harvard Law Review, 4(5), 193-220.

Washington Post. (1992). Oregon woman hangs up phone law; Suit says telemarketing limits discriminate against small business. The Washington Post, A9.

Whittler, R. E. (1989). Viewers's reactions to racial cues in advertising stimuli. Pyschology and Marketing, 31(6). 287-309.

Wong, V., Turner, W., \& Stoneman, P. (1996). Marketing strategies and market prospects for environmentally-friendly consumer products. British Journal of Management, 7(3).

Yamamoto, K., \& Lloyd, R. A. (2019). The role of big data and digitization in just-in-time (JIT) information feeding. American Journal of Management, 19(3). 